\title{
PENERAPAN THINK, TALK, AND WRITE UNTUK MENINGKATKAN KEMAMPUAN BERPIKIR KRITIS DAN HASIL BELAJAR IPS SISWA KELAS VIII SMP KRISTEN SATYA WACANA SALATIGA
}

\author{
Endy Liani Klarita \\ Program Studi Pendidikan Ekonomi FKIP UKSW \\ 162015018@student.uksw.edu \\ Arief Sadjiarto \\ Program Studi Pendidikan Ekonomi FKIP UKSW \\ rifsad@staff.uksw.edu
}

\begin{abstract}
ABSTRAK
This research was conducted with problems in class VIII students, amounting to 20 students at the Satya Wacana Christian Middle School in Salatiga regarding critical thinking skills and learning outcomes. Therefore researchers want to take action to improve learning by using the Think Talk and Write (TTW) model. This type of research is the study of class action using Kurt Lewin's research design. The instrument of data collection uses test instruments, observation sheets, and questionnaires. Analysis of the data used is descriptive comparative. The indicator of the success of critical thinking skills and learning outcomes is $75 \%$. The results obtained from this study are that there is an increase in critical thinking skills and learning outcomes of class VIII Satya Wacana Christian Middle School Salatiga. In the first cycle the results of critical thinking skills are 55\% of students who have high critical thinking skills, while in the second cycle there is an increase of $85 \%$ of students who have high critical thinking skills. Then in the pre-cycle learning outcomes there were $25 \%$ of students whose grades reached KKM, the first cycle there were $70 \%$ of students completed KKM, and in the second cycle there was an increase of $90 \%$ of students who completed KKM. So the conclusion in this study that the use of Think Talk and Write (TTW) learning model can improve critical thinking skills and student learning outcomes in social studies subjects of class VIII Satya Wacana Christian Middle School Salatiga.
\end{abstract}

Keywords: think talk and write, critical thinking skills, learning outcomes

\section{PENDAHULUAN}

Pendidikan merupakan proses memanusiakan manusia dengan memiliki kepribadian yang sesuai dengan etika moral. Menurut Undang-Undang No. 20 Tahun 2003 Tentang Sistem Pendidikan Nasional menyatakan bahwa pendidikan adalah usaha sadar dan terencana untuk mewujudkan suasana belajar dan proses pembelajaran agar peserta didik secara aktif mengembangkan potensi dirinya untuk memiliki kekuatan spiritual keagamaan, pengendalian diri, kepribadian, kecerdasan akhlak mulia, serta keterampilan yang diperlukan dirinya, masyarakat, bangsa dan Negara. Pernyataan tersebut menjelaskan bahwa suasana belajar dan proses pembelajaran menjadi suatu yang penting agar siswa menjadi aktif bahkan secara keterampilan juga dibutuhkan ditiap-tiap siswa. Guru menjadi peran penting untuk membantu pembelajaran siswa selama di dalam kelas, bukan hanya materi yang dibagikan secara keseluruhan tetapi menggunakan suatu strategi yang tepat agar proses pembelajaran dapat terlaksanakan.

Sehubungan dengan pendidikan tentu ada keterkaitan dengan kurikulum yang sekarang sudah diubahkan menjadi Kurikulum 2013 yang kini mulai diterapkan beberapa sekolah di Indonesia termasuk SMP Kristen Satya Wacana. Menurut Chomaidi \& Salamah (2018) dalam kurikulum 2013 ini ada empat aspek penilaian yaitu (1) aspek pengetahuan, (2) aspek keterampilan, (3) aspek sosial, (4) aspek spiritual. Dalam keempat aspek ini Kurikulum 2013 
(K-13) jelas bukan hanya mengenai pengetahuan saja siswa mampu tetapi secara keterampilan menyerap kemudian mengolah materi secara tepat bahkan pemikiran-pemikiran tentu akan dituntut dari setiap siswa dalam berpikir secara terampil kreatif.

Kemampuan berpikir kritis siswa dan hasil belajar merupakan hal penting yang saling berkaitan satu sama lain. Kemampuan berpikir kritis akan membantu bagaimana seorang dapat berpikir secara logis dan melihat dari sudut pandang yang berbeda dari kebiasaan banyak orang. Namun mengenai hal tersebut tentu perlu melalui interaksi antar guru dan siswa melalui pembelajaran. Menurut Suardi, dkk (2012) pembelajaran adalah suatu proses interaksi (hubungan timbal balik) antara guru dengan siswa. Dalam pernyataan tersebut yang menjelaskan bahwa proses pembelajaran yang melibatkan keduanya sangatlah penting karena untuk memahami cara setiap murid menangkap materi tentu berbeda jadi guru harus mampu memunculkan model pembelajaran yang lebih menarik. Di masa yang sudah serba canggih ini ada beberapa guru yang masih menggunakan metode lama yaitu ceramah sedangkan cara siswa menangkap itu sudah lebih berbeda. Siswa lebih senang belajar dengan cara bermain sambil belajar. Menggunakan model pembelajaran think, talk, and write akan lebih menarik untuk diterapkan dalam pembelajaran IPS.

Model pembelajaran think, talk, and write ini merupakan model yang dapat meningkatkan kemampuan siswa dalam berpikir. Think, talk, and write ini memiliki konsep yang cukup menarik untuk pembelajaran IPS. Dalam model ini siswa akan diajak bagaimana berpikir kemudian mengemukakan hasil pemikiran dan menuangkan melalui tulisan apa yang didapatkan. Namun tidak dilakukan secara individu melainkan siswa bekerja secara kelompok agar saat talk (berbicara) itu siswa berdiskusi atau bertukar pemikiran dengan siswa yang lain. Kemudian hasil yang didapat dari diskusi tersebut maka siswa diminta untuk menulis secara individu dari diskusi tersebut.

Menurut Yamin (2007) ada beberapa kegiatan yang perlu dikerjakan dan juga pemikiran yang perlu disadari oleh pengajar yaitu (1) Guru banyak berinteraksi dengan siswa untuk lebih mengerti apa yang sudah mereka ketahui dan fikirkan. (2) Tujuan dan apa yang akan dibuat di kelas sebaiknya dibicarakan bersama sehingga sungguh terlibat. (3) Guru perlu mengerti pengalaman belajar mana yang lebih sesuai dengan kebutuhan siswa. (4) Diperlukan keterlibatan dengan siswa yang sedang berjuang dan kepercayaan terhadap siswa bahwa mereka dapat belajar. (5) Guru perlu mempunyai pemikiran yang fleksibel untuk dapat mengerti dan menghargai pemikiran siswa. Pernyataan tersebut jelas bahwa guru bukan hanya melakukan tugas mengajar tetapi perlu juga untuk interaksi dengan siswa agar dapat megetahui apa yang siswa butuhkan ketika proses belajar mengajar sedang berlangsung serta guru akan lebih paham cara pemahaman dari tiap siswa agar strategi yang digunakan selama proses belajar dapat mencakup semua siswa lebih mengerti materi yang diberikan.

Menurut Yamin dan Ansari (2012) strategi pembelajaran think, talk, and write (TTW) dapat menumbuhkembangkan kemampuan pemecahan masalah. Pernyataan tersebut jelas bahwa di dalam pembelajaran IPS sering ditemukan permasalahan-permasalahan yang cukup global dengan demikian model pembelajaran ini akan sangat membantu siswa untuk berpikir bahkan berbicara dengan teman untuk membagikan ide sebelum menulis. Dengan hasil belajar bahkan cara berpikir siswa SMP Kristen Satya Wacana khususnya kelas VIII yang masih perlu dikembangkan secara berpikir, berbicara karena dalam hal menulis setiap siswa masih bisa menuangkan pendapat tetapi dalam hal menyampaikan atau berbicara siswa masih dikatakan kurang. 
Dalam hal tersebut SMP Kristen Satya Wacana menjadi menarik untuk dijadikan sebagai tempat penelitian. Siswa disana merupakan siswa yang senang berbicara namun tidak memungkinkan bahwa dalam pelajaran mereka benar-benar tangkap. Khususnya siswa kelas VIII yang secara langsung memperhatikan tetapi untuk berpikir secara lebih kreatif belum dapat dipastikan karena ketika diperhadapkan dengan masalah-masalah yang mendua mereka lebih banyak bertanya untuk penjelasan permasalahan tersebut. Jika proses belajar mengajar berlangsung guru akan memberikan sebuah kasus melalui video yang dapat dilihat siswa secara langsung namun cara pemikiran dan sudut pandang yang masih dikatakan belum cukup dengan keadaan dunia yang semakin sekarat ini.

Berdasarkan observasi selama Magang 3 di SMP Kristen Satya Wacana ada juga beberapa permasalahan yang terlihat (1) guru menjelaskan materi siswa tidak memperhatikan, (2) siswa menjadi pasif di kelas, (3) siswa sibuk berbicara dengan teman sebangku, (4) kurang menangkap materi ketika diperhadapkan dengan soal, (5) suasana belajar yang masih membosankan. Bukan hanya itu saja hasil belajar siswa juga dilihat dari tes harian masih ada beberapa anak yang mendapatkan nilai di bawah Kriteria Ketuntasan Minimal (KKM) yaitu 75 dan sekitar 14 anak diantara 20 siswa yang tidak sampai pada target KKM dalam satu kelas. Dengan begitu pentingnya model pembelajaran think, write, and talk yang akan mengajak setiap siswa untuk berpikir, menulis pendapat kemudian menjelaskan. Model pembelajaran ini lebih membawa siswa untuk berpikir lebih keluar dari lingkungan sehari-hari mereka sehingga dengan permasalahan-permasalahan yang timbul dari berbagai belahan dunia akan menjadi sesuatu yang menarik untuk dibahas. Bahkan model pembelajaran ini dapat juga membantu siswa memperbaiki cara mereka berpikir, bahkan membantu siswa untuk berani menyampaikan pendapat secara lisan maupun tertulis.

Ilmu Pengetahuan Sosial (IPS) membahas mengenai fenomena-fenomena dunia yang cukup membosankan jika dijelaskan menggunakan metode ceramah, tetapi dengan menggunakan model pembelajaran ini maka akan lebih menyenangkan. Siswa lebih suka bermain sambil belajar yang membuat mereka lebih nyaman untuk menyerap dan menerima materi yang diberikan. Dengan pembelajaran IPS maka siswa akan menemukan banyak sekali permasalahan-permasalahan yang sering terjadi di sekitar lingkungan dan tentu akan membawa setiap siswa untuk berpikir lebih kritis mengenai fenomena dunia yang terjadi di jaman saat ini. Oleh karena itu pentingnya model pembelajaran Think, Talk, and Write dalam proses pembelajaran yang dapat meningkatkan kemampuan berpikir kritis terhadap membantu siswa berpikir secara kritis sehinggga akan ada hasil yang terlihat diakhir yaitu hasil belajar dari selama pembelajaran dilaksanakan.

\section{KAJIAN TEORI}

\section{Model Pembelajaran Kooperatif}

Model pembelajaran kooperatif merupakan pendekatan yang berfokus pada kelompok kecil dalam bekerja sama agar tercapai tujuan belajar. Menurut Wirawan (2016) model pembelajaran kooperatif merupakan salah satu bentuk pembelajaran yang didasarkan pada paham konstruktivisme, dimana memandang pebelajar sebagai suatu sistem yang dapat membangun pengetahuannya dengan mengasimilasi atau akomodasi informasi baru dari lingkungannya. Kemudian Wirawan juga berpendapat bahwa ada beberapa keuntungan dari model pembelajaran kooperatif ini yaitu (a) mengajarkan siswa menjadi percaya pada guru, (b) kemampuan untuk berfikir, (c) mencari informasi dari sumber lain dan belajar dari siswa lain, (d) mendorong siswa untuk mengungkapkan idenya secara verbal. Jadi model pembelajaran 
kooperatif akan sangat membantu bagaimana siswa berfikir bahkan model ini akan mengajak lebih siswa untuk aktif dengan teman sebangku serta mendorong siswa dalam mengungkapkan pemikiran ataupun pendapat.

Sedangkan menurut Susanto (2013) model pembelajaran dapat melatih siswa lebih aktif, lebih berani mengemukakan pendapat dan bertanggung jawab serta bekerja sama. Dengan demikian model pembelajaran kooperatif ini akan sangat membantu siswa menjadi lebih aktif bahkan berfikir serta mengungkapkan pendapat sehingga dalam proses belajar mengajar hal ini akan sangat membantu guru. Berdasarkan hal tersebut model pembelajaran merupakan cara mengelompokkan siswa agar selama proses pembelajaran yang akan berpusat pada siswa lebih memudahkan guru mengaktifkan siswa serta bekerja sama dengan kelompok dalam menyelesaikan masalah maupun tugas untuk tujuan bersama.

\section{Model Belajar Think Talk and Write}

Think, Talk, and Write diperkenalkan oleh Huinker \& Laughlin (1996) yang menyatakan bahwa model pembelajaran think, talk, and write membangun pemikiran, merefleksi, dan mengorganisasi ide kemudian menguji ide tersebut sebelum peserta didik diharapkan untuk menulis. Alur model pembelajaran think, talk, and write dimulai dari keterlibatan peserta didik dalam berpikir atau berdialog reflektif dengan dirinya sendiri, selanjutnya berbicara dan berbagi ide dengan temannya sebelum peserta didik menulis. Dalam pernyataan tersebut bahwa membangun pemikiran pada siswa akan menjadi hal yang tentu akan membantu cara berpikir pasif ke aktif. Bahkan keterlibatan siswa dalam model ini juga mengajarkan siswa bagaimana berdialog atau mengungkapkan pemikiran mereka secara lisan maupun tertulis.

Menurut Huinker dan Laughlin (dalam Yamin dan Ansari, 2008) bahwa model pembelajaran ini dibangun melalui berpikir, berbicara dan menulis. Dalam pernyataan tersebut jelas menyatakan bahwa dalam kegiatan pembelajaran akan lebih didukung ketika disertakan dengan model pembelajaran yang tentu mengajarkan cara berpikir secara kritis, berbicara secara jelas serta menulis hal-hal penting. Listiana (2013) mengemukakan bahwa model pembelajaran TTW pada dasarnya menggunakan strategi pembelajaran kooperatif yang pelaksanaannya dirancang untuk berfikir dan refleksikan dan untuk mengkoordinasikan ideide serta menguji ide sebelum siswa diminta untuk menulis. Dalam pernyataan tersebut menjelaskan bahwa model pembelajaran TTW ini merupakan strategi yang membantu cara berpikir anak, cara berbicara bahkan menulis yang tentu akan membantu siswa untuk lebih kreatif aktif dalam proses belajar mengajar.

Langkah-langkah Model Pembelajaran Think, Talk, and Write menurut Yamin dan Ansari (2012) adalah (1) Guru membagi teks bacaan berupa Lembar Kerja Siswa (LKS) yang di dalamnya memuat masalah atau soal terkait materi yang sedang dipelajari untuk dikerjakan oleh siswa dan didalamnya disertai petunjuk serta prosedur pelaksanaannya; (2) Siswa membaca teks bacaan berupa Lembar Kerja Siswa (LKS) yang diberikan kemudian membuat catatan kecil secara individual (think) untuk selanjutnya dibawa ke forum diskusi; (3) Siswa menyampaikan apa yang telah didapatkan pada tahap think kemudian berdiskusi dengan teman sekelompoknya membahas catatan yang telah dibuat masing-masing anggota (talk); (4) Dari hasil diskusi, siswa mengkontruksi sendiri pengetahuan mereka ke dalam diskusi (write) sebagai hasil diskusi kolaborasi; dan (5) Pembelajaran diakhiri dengan membuat refleksi dan kesimpulan dari materi yang telah dipelajarinya. Sebelumnya dipilih satu atau beberapa siswa sebagai perwakilan kelompok untuk menyampaikan hasil diskusinya sedangkan kelompok lain memberi tanggapan. 


\section{Kemampuan Berpikir Kritis}

Menurut Maulana (2017) bahwa berpikir merupakan suatu aktivitas pribadi manusia yang mengakibatkan penemuan yang terarah kepada suatu tujuan. Berpikir kritis adalah kemampuan manusia yang sangat mendasar karena dapat mendorong seseorang untuk selalu memandang setiap permasalahan yang dihadapinya secara kritis. Berdasarkan pernyataan tersebut bahwa berpikir kritis adalah kemampuan yang dapat mendorong kemampuan seorang untuk bisa melihat dari sudut pandang yang berbeda ketika diperhadapkan dengan penemuan dan permasalahan yang ada sehingga seorang akan lebih mudah menemukan solusi diluar pemikiran kebanyakan manusia yang hanya berpikir secara mudah namun sudah sering ditemukan.

Sedangkan menurut Fisher (2009) bahwa berpikir kritis adalah aktivitas terampil, yang dapat memenuhi beragam standar intelektual, seperti kejelasan, relevansi, kecukupan, koherensi. Dalam pernyataan tersebut dapat dipahami bahwa berpikir kritis berarti berbicara mengenai komunikasi yang membantu kejelasan cara manusia berpikir secara relevansi sehingga seorang berbicara tentu harus memiliki dasar yang kuat agar ketika dipergoncangkan dengan pemikiran yang lebih hebat pendapat tersebut akan lebih mudah diperkuat secara jelas.

Berdasarkan dari uraian tersebut bahwa ada empat faktor yang mempengaruhi kemampuan berpikir kritis. Yang pertama adalah kondisi fisik merupakan kebutuhan yang paling dasar bagi manusia karena ketika kondisi fisik siswa itu terganggu maka siswa tidak dapat berpikir cepat serta berkonsentrasi dalam memecahkan masalahnya dan tubuhnya tidak dapat bereaksi terhadap respon yang ada. Faktor yang kedua adalah motivasi merupakan hasil faktor internal yang dapat menimbulkan rangsangan serta dorongan yang memperlihatkan daya serap belajar sehingga siswa menjadi timbul keingintahuan dalam mencapai tujuan yang ditetapkan. Faktor ketiga, kecemasan merupakan keadaan emosional yang dapat timbul secara otomatis sehingga menimbulkan kecemasan atau ketakutan pada siswa dan dapat membatasi siswa dalam berpikir. Faktor keempat adalah perkembangan intelektual merupakan kemampuan mental siswa untuk merespon serta menyelesaikan persoalan sehingga siswa dapat menghubungkan persoalan yang satu dengan persoalan yang lain. Jadi intelektual atau kecerdasan ini disesuaikan dengan usia dan tingkah perkembangannya.

\section{Hasil Belajar}

Menurut Sinar (2018) hasil belajar merupakan perubahan perilaku yang dipengaruhi oleh lingkungan serta bentuk prestasi yang dicapai oleh seseorang dari kemampuan hasil belajar. Dalam pernyataan tersebut hasil belajar hal penting yang dapat dilihat bagaimana hasil akhir yang didapatkan siswa sehingga dapat dijadikan evaluasi guru dalam proses pembelajaran selama dikelas untuk menentukan target yang dicapai siswa di hasil akhir setelah pembelajaran selesai dilaksanakan.

Sedangkan menurut Susanto (2013) hasil belajar adalah kemampuan yang diperoleh anak setelah melalui kegiatan belajar. Dari pernyataan tersebut menjelaskan bahwa kegiatan belajar menjadi bagian terpenting untuk hasil belajar siswa karena dari proses belajar mengajar yang menyenangkan serta membantu siswa untuk lebih jelas memahami materi akan lebih baik dalam hasil akhirnya nanti.

Keputusan hasil belajar adalah umpan balik bagi siswa dan guru karrena hasil belajar merupakan hasil akhir yang terlihat bagaimana selama proses belajar mengajar selama berlangsung. Menurut Aisyah (2015) jenis-jenis hasil belajar dapat dilihat dalam tiga ranah yaitu ranah kognitif, afektif, dan psikomotor. Ranah kognitif berorientasi pada kemampuan 
berpikir yang paling sering dipergunakan yakni (a) pengertian atau pemahaman serta mendefinisikan dengan kata sendiri. (b) memberikan contoh dengan tepat untuk memecahkan masalah. (c) analisis dengan menguraikan. (d) menyimpulkan. (e) evaluasi. Ranah afektif berhubungan dengan perasaan, emosi, system nilai, dan sikap yang menunjukkan penerimaan atau penolakan terhadap sesuatu. Jenis ranah afektif ini tampak kepada tingkah laku siswa dalam memperhatikan pelajaran, bersikap disiplin bahkan kebiasaan belajar. Ranah psikomotorik berorientasi dalam bentuk keterampilan dan kemampuan bertindak secara individu.

Berkaitan dengan jenis hasil belajar tersebut dikemukakan bahwa hasil belajar merupakan perubahan tingkah laku yang mencakup aspek kognitif, aspek afektif, dan aspek psikomotorik. Berdasarkan kedua pendapat tersebut, dapat dipahami makna hasil belajar adalah perubahan perilaku serta puncak proses belajar yang dapat memperlihatkan kemampuan siswa selama proses belajar berlangsung sehingga hasil akhir dari proses tersebut.

\section{METODE PENELITIAN}

Penelitian ini menggunakan jenis penelitian tindakan kelas (PTK) yang bertujuan untuk mengetahui peningkatan kemampuan berpikir kritis siswa dengan memperbaiki kegiatan pembelajaran menggunakan model pembelajaran Think Talk and Write. Subjek penelitian ini adalah siswa kelas VIII yang berjumlah 20 siswa. Penelitian ini dilaksanakan pada hari Kamis, 21 Maret 2019 dan Senin, 1 April 2019. Dalam penelitian ini dilaksanakan dalam 2 siklus dengan teknik pengumpulan data observasi, dokumentasi, angket, dan tes. Teknik analisis data menggunakan statistik deskriptif komparatif yaitu teknik statistik presentase dengan membandingkan hasil belajar berdasarkan ketuntasan prasiklus, siklus, I, dan siklus II.

\section{HASIL DAN PEMBAHASAN \\ Hasil Penelitian \\ Data Prasiklus}

Hal ini dapat dilihat dari ketuntasan minimal yang diperoleh siswa dari tes awal pada tanggal 11 Maret 2019 yang dikuti oleh 20 siswa kelas VIII B SMP Kristen Satya Wacana Salatiga. Hasil tes awal menunjukkan bahwa banyak siswa yang mendapatkan nilai di bawah KKM yaitu 75, hal tersebut dapat dilihat pada tabel 1.

Tabel 1. Hasil Belajar IPS Prasiklus

\begin{tabular}{|c|c|c|c|}
\hline Nilai & Frekuensi & Presentase & Keterangan \\
\hline$\geq 75$ & 5 & $25 \%$ & Tuntas \\
\hline$<75$ & 15 & $75 \%$ & Tidak Tuntas \\
\hline Jumlah & 20 & \multicolumn{2}{|c|}{100} \\
\hline Rata-rata Kelas & & 60.5 & \\
\hline
\end{tabular}

Sumber : hasil nilai ulangan IPS terakhir kelas VIII

Berdasarkan tabel 1, perolehan nilai dengan tabel distribusi frekuensi, dapat diketahui bahwa nilai tes awal rata-rata kelas yaitu 60,5 dari 20 siswa yang mengikuti tes awal. Kriteria ketuntasan minimal dalam penelitian ini adalah 75 dengan nilai terendah 37 , sedangkan nilai tertinggi adalah 81 sehingga belum ada siswa yang tuntas. Hasil tersebut dalam menerapkan model Think, Talk, and Write diharapkan dapat meningkatkan hasil belajar dalam pembelajaran IPS siswa kelas VIII SMP Kristen Satya Wacana Salatiga semester genap 2018/2019. 


\section{Tindakan Siklus I}

Peningkatan hasil belajar IPS menggunakan model Think, Talk, and Write melalui penilaian hasil belajar siswa dengan pemberian soal di akhir pembelajaran. Hasil belajar IPS yang dicapai oleh siswa pada siklus I dapat dilihat pada tabel 2.

Tabel 2. Hasil Belajar IPS Siklus I

\begin{tabular}{|c|c|c|c|}
\hline Nilai & Frekuensi & Presentase & Keterangan \\
\hline$\geq 75$ & 14 & $70 \%$ & Tuntas \\
\hline$<75$ & 6 & $30 \%$ & Tidak Tuntas \\
\hline Jumlah & 20 & & \\
\hline
\end{tabular}

Sumber : hasil nilai ulangan IPS kelas VIII

Berdasarkan tabel 2 dapat dilihat bahwa hasil belajar 20 siswa diperoleh nilai rata-rata yaitu 79,25. Nilai tertinggi pada siklus I yaitu 95 sedangkan nilai terendah yaitu 40. Jumlah siswa yang tuntas atau mencapai KKM 75 sebanyak 6 siswa dengan persentase 30\%, sedangkan siswa yang belum mencapai KKM 75 sebanyak 14 siswa dengan persentase $70 \%$. Berdasarkan penilaian tersebut maka ketuntasan pembelajaran pada siklus I belum mencapai target yang diharapkan dalam indikator kinerja penelitian yaitu $75 \%$ dari jumlah siswa yang mengikuti pembelajaran.

Tabel 3. Hasil Analisis Kemampuan Berpikir Kritis Siklus I

\begin{tabular}{|c|c|c|}
\hline Nilai & frekuensi & Presentase \\
\hline$>3$ (Kemampuan berpikir kritis tinggi) & 11 & $55 \%$ \\
\hline$<3$ (Kemampuan berpikir kritis rendah) & 9 & $45 \%$ \\
\hline
\end{tabular}

Sumber : data hasil analisis

Tabel 3 menjelaskan bahwa hasil analisis kemampuan berpikir kritis pada siklus I dari 20 siswa hanya 11 siswa yang kemampuan berpikir kritisnya tinggi atau sudah mencapai skor nilai rata-rata $>3$ dengan presentasenya adalah 55\%, sedangkan 9 siswa yang kemampuan berpikir kritisnya rendah atau belum memenuhi ketercapaian skor nilai rata-rata $<3$ dengan presentasenya $45 \%$. Hasil presentase tersebut belum mencapai indikator keberhasilan yaitu 75\% maka diperlukan 20\% lagi untuk mencapai target yang diharapkan. Hasil analisis kemampuan berpikir kritis siswa dapat dilihat pada gambar 1.

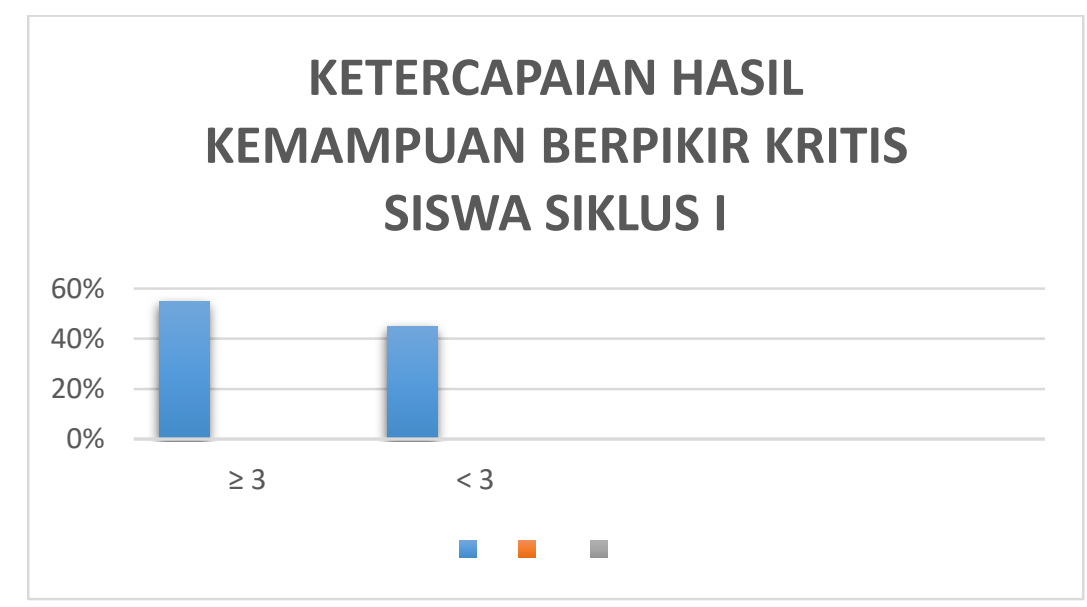

Gambar 1. Grafik hasil kemampuan berpikir kritis siswa siklus I 


\section{Tindakan siklus II}

Hasil belajar pembelajaran IPS akan dilihat dari tes evaluasi yang dikerjakan siswa pada siklus II kelas VIII B SMP Kristen Satya Wacana dengan kriteria ketuntasan minimal yaitu 75 mengalami peningkatan. Berikut tabel hasil belajar pembelajaran IPS yang diperoleh siswa pada siklus II.

Tabel 4. Hasil Belajar IPS Siklus II

\begin{tabular}{|c|c|c|c|}
\hline Nilai & Frekuensi & Presentase & Keterangan \\
\hline$\geq 75$ & 18 & $90 \%$ & Tuntas \\
\hline$<75$ & 2 & $10 \%$ & Tidak Tuntas \\
\hline Jumlah & 20 & \multicolumn{2}{|c|}{100} \\
\hline Rata-rata Kelas & & 79.65 & \\
\hline
\end{tabular}

Sumber : hasil belajar IPS siklus II

Berdasarkan tabel 4 bahwa hasil belajar 20 siswa diperoleh nilai rata-rata yaitu 79,65. Nilai tertinggi pada siklus I yaitu 98 sedangkan nilai terendah yaitu 60. Jumlah siswa yang tuntas atau mencapai KKM 75 sebanyak 18 siswa dengan persentase 90\%, sedangkan siswa yang belum mencapai KKM 75 sebanyak 2 siswa dengan persentase 10\%. Berdasarkan penilaian tersebut maka ketuntasan pembelajaran pada siklus II sudah mencapai target yang diharapkan dalam indikator kinerja penelitian yaitu 75\% dari jumlah siswa yang mengikuti pembelajaran.

Tabel 5. Hasil Analisis Kemampuan Berpikir Kritis Siklus II

\begin{tabular}{ccc}
\hline Nilai & frekuensi & Presentase \\
\hline$>3($ Kemampuan berpikir kritis tinggi) & 17 & $85 \%$ \\
\hline$<3$ (Kemampuan berpikir kritis rendah) & 3 & $15 \%$ \\
\hline
\end{tabular}

Tabel 5 menunjukkan bahwa terjadi peningkatan pada kemampuan berpikir kritis siswa kelas VIII SMP Kristen Satya Wacana Salatiga. Dari hasil tersebut bahwa dari terdapat 3 siswa yang tidak mencapai skor nilai rata-rata $>3$ dengan presentase $15 \%$ sedangkan terdapat 17 siswa yang mencapai skor nilai rata-rata $>3$ dengan presentase $85 \%$ yang berarti bahwa terjadi peningkatan pada siklus II disbandingkan siklus I yaitu 20 siswa atau $85 \%$ siswa yang kemampuan berpikir kritisnya tinggi. Hasil analisis kemampuan berpikir kritis siswa dapat dilihat pada gambar 2 .

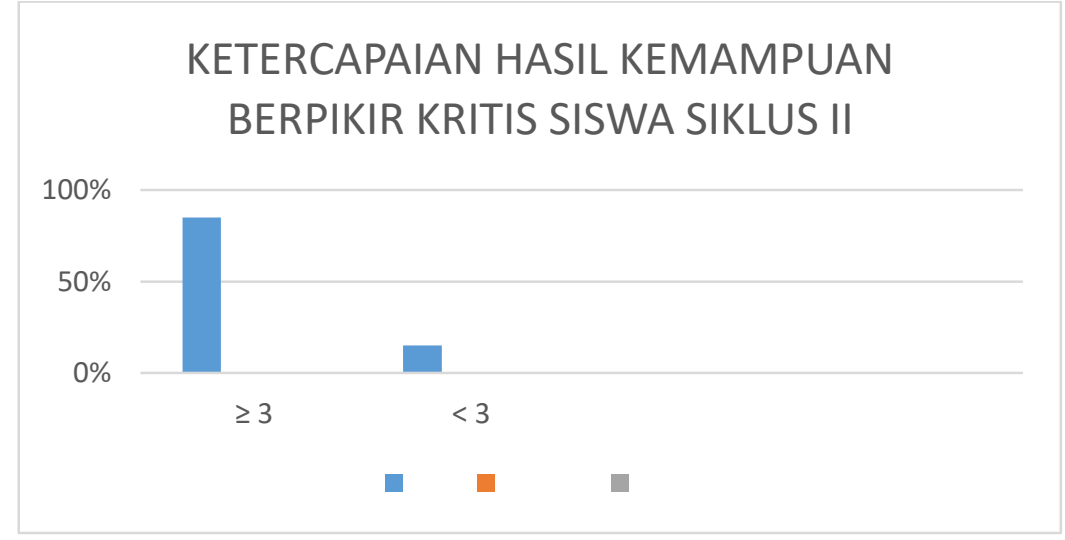

Gambar 2. Grafik ketercapaian hasil kemampuan berpikir kritis siswa siklus II 


\section{PEMBAHASAN}

Penerapan model pembelajaran Think Talk and Write dalam pembelajaran IPS untuk meningkatkan kemampuan berpikir kritis dan hasil belajar pada siswa kelas VIII SMP Kristen Satya Wacana Salatiga tahun pelajaran 2018/2019 dilaksanakan selama 2 siklus. Fisher (2009) memandang bahwa berpikir kritis merupakan aktivitas yang membantu siswa dalam memenuhi beragam standar intelektual seperti kejelasan cara berpikir yang dapat mengarahkan siswa pada pemikiran kritis secara relevansi. Perubahan dalam perilaku siswa tersebut dapat menunjukkan kecenderungan siswa untuk mendapatkan hasil belajar sebaik mungkin. Definisi tersebut mendukung peneliti dalam meningkatkan kemampuan berpikir kritis siswa karena berpikir kritis mendorong ketercapaian hasil belajar siswa.

Berdasarkan hasil penelitian mengenai kemampuan berpikir kritis dan hasil belajar siswa kelas VIII SMP Kristen Satya Wacana Salatiga dengan menggunakan model Think Talk and Write. Maka dapat diketahui bahwa penggunaan model TTW telah meningkatkan hasil belajar siswa. Siswa kelas VIII terdiri dari 12 laki-laki dan 8 perempuan dengan karakter siswa yang sebagian besar tidak percaya diri untuk mengungkapkan pendapat dan masih malu untuk bertanya ketika peneliti melakukan observasi di kelas VIII pada mata pelajaran IPS. Hal tersebut terlihat ketika guru meminta salah satu untuk mengungkapkan pendapat mengenai suatu kasus pada materi pelajaran dan diminta untuk bertanya mengenai pembelajaran yang belum jelas atau belum dipahami, siswa kebanyakan diam dan menolak.

Hal itu terjadi karena metode yang digunakan masih menggunakan ceramah dan hanya terpaku pada buku pelajaran. Namun kemampuan berpikir kritis dan hasil belajar siswa mengalami peningkatan setelah diterapkannya model Think Talk and Write (TTW). Menurut Rani Rahmawati, dkk (2015) bahwa model Think Talk and Write dapat meningkatkan kemampuan berpikir kritis siswa. Pendapat ini diperkuat oleh Shoimin (2014) yang menyatakan bahwa (a) siswa siswa dapat mengembangkan pemecahan terkait bahan ajar serta memahami, (b) dengan soal open ended keterampilan berpikir kritis siswa dapat di kembangkan, (c) dengan berinteraksi dan bediskusi antar kelompok akan melibatkan siswa untuk aktif dalam pembelajaran, (d) membiasakan siswa untuk berpikir dan berkomunikasi dengan teman, guru, bahkan diri sendiri. Model belajar ini menekankan siswa untuk aktif dalam berpikir, berbicara serta menulis dan bekerjasama di dalam kelompok.

Pada saat siklus I dilakukan, sudah terlihat bagaimana siswa antusias untuk bertanya menjawab walau masih terlihat siswa yang berbicara dengan teman sekelilingnya. Perilaku siswa menunjukkan hasil 55\% kemampuan berpikir kritis siswa pada siklus I, sedangkan siklus II 85\% siswa yang mempunyai kemampuan berpikir kritis tinggi dengan rata-rata perolehan nilai $\geq 3$. Hal tersebut membuktikan bahwa keberhasilan dari penerapan model pembelajaran TTW dalam peningkatan kemampuan berpikir kritis siswa.

Seperti halnya bahwa kemampuan berpikir kritis merupakan cara seseorang memecahkan atau memaparkan segala sesuatu dengan dasar yang tepat dan secara relevan. Menurut Sudjana (2010) bahwa hasil belajar merupakan hasil siswa setelah melakukan kegiatan pembelajaran sebagai kemampuan siswa untuk melihat hasil selama proses pembelajaran siswa di kelas selama menerima pembelajaran. Definisi tersebut mendukung peneliti dalam melakukan penelitian karena hasil belajar yang diperoleh siswa kelas VIII pada mata pelajaran IPS melalui kegiatan pembelajaran yang dilakukan setiap siklus. 
Hasil penelitian menyatakan bahwa terjadi peningkatan setelah peneliti melakukan proses pembelajaran dengan menerapkan model Think Talk and Write (TTW). Pada siklus I terlihat bahwa perbedaan hasil pada prasiklus hanya $25 \%$,setelah diterapkannya model belajar TTW diperoleh siklus 70\% yang mendapatkan nilai $\geq 75$, dan pada siklus II terjadi peningkatan lagi yaitu 90\% siswa yang memperoleh nilai di atas $\geq 75$ atau tuntas KKM.

Penelitian ini sejalan dengan penelitian Resdiyanti (2013) bahwa kondisi awal menunjukkan hasil kemampuan berpikir kritis siswa hanya mencapai 30\% dengan indikator pencapaian $80 \%$. Setelah dilakukan penerapan model belajar TTW didapati hasil 95\% kemampuan berpikir kritis tinggi, hasil tersebut di atas indikator pencapaian yang telah ditargetkan. Kemudian untuk hasil belajar siswa pada kondisi awal hanya $20 \%$ siswa yang mencapai nilai di atas KKM (75). Setelah dilakukan tindakan dengan menerapkan model belajar TTW pada siklus I, hasil belajar siswa meningkat menjadi 70\% tuntas KKM dan siklus II diperoleh 95\% tuntas KKM. Penelitian ini membuktikan bahwa peningkatan terhadap kemampuan berpikir kritis dan hasil belajar siswa setelah menerapkan model pembelajaran TTW. Penelitian tersebut mempunyai kesamaan dan perbedaan dengan penelitian yang dilakukan peneliti. Kesamaannya adalah model belajar yang digunakan yaitu Think Talk and Write (TTW) dan variabel yang diteliti yaitu kemampuan berpikir kritis dan hasil belajar. Sedangkan perbedaannya adalah terletak pada jumlah siswa pada penelitian Resdiyanti yaitu 32 siswa dan jumlah siswa peneliti 20.

\section{SIMPULAN}

Penggunaan model pembelajaran Think Talk and Write (TTW) dalam mata pembelajaran IPS pada siswa kelas VIII di SMP Kristen Satya Wacana Salatiga dapat meningkatkan kemampuan berpikir kritis siswa. Melalui penggunaan model pembelajaran Think Talk and Write (TTW) dalam mata pembelajaran IPS pada siswa kelas VIII di SMP Kristen Satya Wacana Salatiga dapat meningkatkan hasil belajar siswa. Dari data prasiklus terdapat 5 siswa yang tuntas atau dalam presentasenya adalah $25 \%$. Namun setelah dilakukan tindakan melalui model pembelajaran TTW pada siklus I terdapat peningkatan hasil belajar dan terdapat 14 siswa yang berhasil mencapai KKM atau dalam presentase adalah $70 \%$. Sedangkan pada siklus II terdapat peningkatan yaitu ada 18 siswa yang mencapai ketuntasan yaitu $90 \%$ dan siswa yang belum tuntas hanya 2 siswa jika dipresentasekan menjadi $10 \%$.

Dengan adanya peningkatan kemampuan berpikir kritis hal ini memicu peningkatan hasil belajar pada siswa. Peningkatan ini terjadi karena adanya penerapan model belajar TTW pada mata pelajaran IPS. Pada pembagian kelompok model TTW, siswa dibagi ke dalam 4 kelompok yang terdapat 5 siswa pada satu kelompok, kemudian guru membagikan Lembar Kerja Siswa pada setiap kelompok. Langkah-langkah pelakasanaan model TTW adalah (1) guru menjelaskan cara mengisi Lembar Kerja Siswa untuk pengisian tepatnya; (2) siswa akan berdiskusi untuk jawaban penjelasan yang sesuai dengan pertanyaan yang sudah tertulis pada LKS tersebut; (3) guru akan memanggil perwakilan setiap kelompok untuk mempresentasikan hasil diskusi di depan kelas; (4) siswa yang lain akan memberikan pertanyaan kepada kelompok yang maju; (5) siswa yang aktif dan kelompok yang memberikan jawaban secara tepat akan mendapat poin tambahan pada nilai mereka; (6) guru dan siswa membuat kesimpulan dari kegiatan pembelajaran. 
Dari hasil penelitian ini, jika siswa kurang menyukai pembelajaran secara individu, lakukanlah secara kelompok seperti berdiskusi secara kelompok, presentasi, dan tanya jawab mengenai materi yang belum dipahami agar melatih kemampuan berpikir kritis siswa. Guru IPS dapat memadukan model pembelajaran TTW atau model pembelajaran lainnya yang sesuai dengan karakteristik siswa agar siswa tidak merasa bosan selama pembelajaran dan melatih siswa untuk berpikir, berbicara serta mengeluarkan pendapat mereka melalui tulisan. Sebagai lembaga pendidikan sekolah hendaknya memberikan dorongan pada setiap guru yang mengajar untuk memberikan penerapan pembelajaran yang tidak membosankan khususnya pada mata pelajaran IPS agar siswa lebih aktif untuk memahami pembelajaran tersebut serta melihat ke lingkungan yang berkaitan dengan pembelajaran. Penelitian ini dapat dilanjutkan oleh peneliti selanjutnya dengan menambah satu atau dua variabel yang berbeda dan dapat sesuai dengan penggunaan model pembelajaran Think Talk and Write.

\section{DAFTAR PUSTAKA}

Aisyah, S. (2015). Perkembangan peserta didik \& bimbingan belajar. Yogyakarta: CV Budi Utama.

Chomaidi \& Salamah. (2018). Pendidikan dan pengajaran : Strategi pembelajaran sekolah. Jakarta. Kompas Gramedia.

Fisher, A. (2009). Berpikir kritis sebuah pengantar. Jakarta: Penerbit Erlangga.

Huinker, D., \& Laughlin, C. (1996). Talk your way into writing, in communication in mathematics k-12 and beyond, 1996 year book. The National Counsil of Teacher of Mathematics.

Khosim, N. (2017). Model-model pembelajaran. Surabaya: Surya Media Publishing.

Kunandar. (2012). Langkah mudah penelitian tindakan kelas sebagai pengembangan profesi guru. Jakarta. PT Raja Grafindo Persada.

Listiana, L. (2013). Pemberdayaan Keterampilan Berpikir dalam Pembelajaran Biologi melalui Model Kooperatif Tipe GI (Group Investigation) dan TTW (Think, Talk, Write). In Proceeding Biology Education Conference: Biology, Science, Enviromental, and Learning (Vol. 10, No. 1).

Maulana. (2017). Konsep dasar matematika dan pengembangan kemampuan berpikir kritiskreatif. Sumedang: Upi Sumedang Press.

Republik Indonesia. (2003). Undang-Undang Republik Indonesia Nomor 20 Tahun 2003 tentang Sistem Pendidikan Nasional.

Resdiyanti, I. (2013). Penerapan model pembelajaran Think Talk Write (TTW) untuk meningkatkan kemampuan berpikir kritis dan hasil belajar geografi siswa kelas XI IPS 1 SMA Negeri 11 Lawang Kabupaten Malang. Diakses http://library.um.ac.id/ptk/index.php?mod=detail\&id=60356

Rukajat, A. (2018). Penelitian tindakan kelas. Yogyakarta: CV Budi Utama.

Sinar. (2018). Metode active learning. Yogyakarta: CV Budi Utama.

Siska, Y. (2016). Konsep dasar IPS. Yogyakarta: Garudhawaca.

Solihatin, E. dkk. (2011). Cooperative Learning Analisis Model Pembelajaran IPS. Jakarta: Bumi Aksara. 
Suardi, dkk. (2012). Belajar \& pembelajaran. Yogya. Penerbit Deepublish.

Susanto, A. (2013). Teori belajar \& pembelajaran di Sekolah Dasar. Jakarta: Prenadamedia Group.

Waluya, B. (2006). Sosiologi menyelami fenomena sosial di masyarakat. Bandung: PT Setia Purna Inves.

Wirawan, K. (2016). Model pembelajaran kooperatif TTW(Cooperative TTW learning model). Singaraja: Universitas Pendidikan Ganesha.

Yamin, M. \& Ansari, B.I. (2012). Taktik mengembangkan kemampuan individual siswa. Jakarta: Referensi.

Yamin, M. (2007). Strategi pembelajaran berbasis kompetensi. Jakarta: Gaung Persada. 